\title{
THE MEANING OF NEUTROPENIA AND HOMECARE NEEDS ACCORDING TO CAREGIVERS OF CHILDREN WITH CANCER ${ }^{1}$
}

Débora Duarte Gelesson ${ }^{2}$ Liliane Yumi Hiraishi ${ }^{3}$ Letícia Alves Ribeiro ${ }^{4}$ Sonia Regina Pereira ${ }^{5}$

Maria Gaby Rivero de Gutiérrez ${ }^{6}$ Edvane Birelo Lopes De Domenico ${ }^{5}$

Gelesson DD, Hiraishi LY, Ribeiro LA, Pereira SR, Gutiérrez MGR, De Domenico EBL. The meaning of neutropenia and homecare needs according to caregivers of children with cancer. Rev Latino-am Enfermagem 2009 novembrodezembro; 17(6):933-9.

This study aimed to understand the meanings caregivers attributed to the process of caring for a neutropenic child at home and know their needs for orientation related to care for these children. This descriptive study was carried out at the Pediatric Oncology Institute through semi-structured interviews, involving eleven caregivers. Data were organized according to the content analysis technique and interpreted according to Social Representations theory. Results indicate changes in the physical environment, people and human relationships, evidencing crises and transition towards stability. The following care procedures raised doubts: hyperthermia, body, food and environmental hygiene, risks of interpersonal contact and special care. The conclusion is that caregivers need technical and emotional preparedness to cope with the reported difficulties, including aggravating situations.

DESCRIPTORS: medical oncology; neutropenia; child care; health education

\section{EL SIGNIFICADO DE LA NEUTROPENIA Y LAS NECESIDADES ORIENTACIÓN SOBRE EL CUIDADO, EN EL DOMICILIO, QUE NECESITAN LOS CUIDADORES DE NIÑOS CON CÁNCER}

Este estudio tuvo como objetivo comprender los significados atribuidos por los cuidadores al proceso de cuidar de un niño neutropénico, en su domicilio, y conocer las necesidades de orientaciones para el cuidado de esos niños. Es un estudio descriptivo, realizado en el Instituto de Oncología Pediátrica, con once cuidadores, utilizando entrevista semiestruturada. Los datos fueron organizados según la técnica de análisis de contenido e interpretados bajo el marco teórico de las Representaciones Sociales. Los resultados indican cambios en el ambiente físico, en las personas y en las relaciones humanas, evidenciando fases de crisis y de transición para obtener la estabilidad. Los cuidados que generaron dudas fueron: hipertermia, higiene corporal, del ambiente y de los alimentos, riesgos de contacto interpersonal y cuidados especiales. Se concluye que existe necesidad de preparar técnicamente $y$ emocionalmente a los cuidadores para el enfrentamiento de las dificultades apuntadas, incluyendo las condiciones de agravamiento.

DESCRIPTORES: oncología médica; neutropenia; cuidado del niño; educación en salud

\section{SIGNIFICADO DA NEUTROPENIA E NECESSIDADES DE CUIDADO EM DOMICÍLIO PARA OS CUIDADORES DE CRIANÇAS COM CÂNCER}

Este estudo objetivou compreender os significados atribuídos pelos cuidadores ao processo de cuidar de uma criança neutropênica, em domicílio, e conhecer as necessidades de orientações para o cuidado dessas crianças. É estudo descritivo, realizado no Instituto de Oncologia Pediátrica, com onze cuidadores, utilizando entrevista semiestruturada. Os dados foram organizados segundo a técnica de análise de conteúdo e interpretados à luz das Representações Sociais. Os resultados indicam mudanças no ambiente físico, nas pessoas e nas relações humanas, evidenciando fases de crise e de transição para a estabilidade. Os cuidados que geraram dúvidas foram: hipertermia, higiene corporal, do ambiente e dos alimentos, riscos do contato interpessoal e cuidados especiais. Conclui-se que há necessidade de preparo técnico e emocional dos cuidadores para o enfrentamento das dificuldades apontadas, incluindo as condições de agravamento.

DESCRITORES: oncologia; neutropenia; cuidado da criança; educação em saúde

${ }^{1}$ Article extracted from specialization course conclusion monograph. Nursing Course, Escola Paulista de Medicina, Universidade Federal de São Paulo, Brazil. ${ }^{2}$ RN, Hospital e Maternidade Santa Marina, Sao Paulo, Brazil, e-mail: deboradgelesson@yahoo.com.br. ${ }^{3}$ RN, Trainee in Oncology, Hospital das Clínicas, Faculdade de Medicina, Universidade de São Paulo, Brazil, e-mail: hiraishi_ly@yahoo.com.br. ${ }^{4}$ RN, Instituto de Oncologia Pediátrica, Grupo de Apoio ao Adolescente e à Criança com Câncer - GRAACC, Sao Paulo, Brazil, e-mail: leticia alvesribeiro@yahoo.com.br. ${ }^{5}$ Adjunct Professor, Universidade Federal de Sao Paulo, Brazil, e-mail: sore@denf.epm.br, edvane@denf.epm.br. ${ }^{6}$ Associate Professor, Universidade Federal de São Paulo, Brazil, e-mail: mgutierrez@denf.epm.br. 


\section{INTRODUCTION}

Among treatments provided to children with cancer, antineoplastic chemotherapy is one of the most important and promising ways to fight cancer ${ }^{(1-}$ 2). Chemotherapy drugs can cause pancytopenia in hematopoietic tissue, which is characterized by the reduction of red blood cells, leukocytes (especially neutrophils) and platelets, generated by the specific action of these drugs ${ }^{(3)}$.

Education and care are used to minimize the risk of complications related to neutropenia. This is a vulnerable condition, whether the child is hospitalized or receives care at home. It is the role and responsibility of nurses to plan and implement educative actions so as to maintain and recover the patients' health condition, aiming to integrate these children into society, working with different aspects of values and attitudes, such as: respect, hygiene, and care delivery at the bodily and emotional levels ${ }^{(1,4)}$.

In this perspective, the goal of this study was to understand how caregivers interpret the process of caring for a child with neutropenia and the peculiar needs they have, with a view to obtaining support for the future planning and practice of educative activities in nursing. The following questions guided the study:

- what is the meaning of caring for a child with neutropenia in the perspective of the caregiver? What does it mean for caregivers to take care of a child with neutropenia?

- what are the needs caregivers present in relation to orientations during daily care provided to children with neutropenia at home?

\section{OBJECTIVES}

To understand the meanings caregivers attribute to the process of caring for a child with neutropenia at home.

To know the needs caregivers present in relation to orientations for home care to a child with neutropenia.

\section{THEORETICAL FRAMEWORK}

Knowledge originated in Social Representation was used, especially related to the understanding that consensual realities use reified universes as raw material ${ }^{(5)}$. Consensual reality includes intellectual activity of daily life, "common sense theories", that is, "a body of knowledge spontaneously produced by members of a group and based on tradition and consensus $^{\prime \prime}{ }^{(5)}$, which suffers continuous appropriations of images, concepts and language that science (in this reified universe) launches on the contemporary world by the various means of communication (radio, television, internet, magazines among others) ${ }^{(5-6)}$.

This process is permeated by the transference and transformation of knowledge that will be explicit in the elaboration of behavior, as well as in the form and content of communication among individuals ${ }^{(6)}$. The construction of symbolic meanings will be simultaneously a cognitive and an affective act.

In this study, caregivers of children with cancer and with neutropenia present their own meanings regarding the illness process, risks inherent to the diagnosis, the treatment and its consequences, constituted in the experience of this process and in environments shared in hospital facilities.

This way, we intended to unveil these caregivers' universe of representations to the extent that it can show the rationale of behavior and action (linked to representational beliefs). It is important to highlight that the beliefs of caregivers are reflected in their actions because they believe in the knowledge they have.

\section{METHOD}

Study design

This is a descriptive quantitative and qualitative study. Qualitative analysis is justified because this research method permits incorporating meaning and intentionality as inherent to acts, social relationships and structures ${ }^{(7)}$.

Setting

The study was carried out in the Chemotherapy Outpatient clinic of the Pediatric Oncology Institute (IOP-GRAACC), which is a nonprofit institution, located in the city of São Paulo, SP, Brazil. 
Subjects

This study was carried out with 11 caregivers of children with cancer, who met the following inclusion criteria:

- being the main caregiver of a child with cancer receiving chemotherapy treatment;

- being previously informed about the risks of postchemotherapy neutropenia;

- having cared for a child at home after antineoplastic chemotherapy.

Data collection

Ethical aspects

Field research was initiated after approval and authorization were obtained from the Research Ethics Committee at São Paulo Federal University. The guidelines specified by Resolution 196/96 from the National Health Council were followed, aiming to ensure the participants' rights. Subjects formally manifested consent by signing the free and informed consent term.

\section{Characterization of the sample}

We initially attempted to identify the individual and social context of the participants by analyzing patients' files and then directly approaching caregivers. Data were collected in October 2007 through a semi-structured questionnaire, tape recorded and fully transcribed afterwards.

Semi-structured questions

- describe what it is/was like to care for a child with neutropenia at home

- which procedures generated the greatest doubts?

- which procedures you feel needed orientations?

Data analysis

Quantitative data are presented in absolute figures, percentages and averages. Content Analysis ${ }^{(8)}$ technique was used for the analysis of qualitative data, which originated three representational schemes that were analyzed through the Social Representations framework.

\section{RESULTS}

\section{Characterization of the sample}

Ten mothers and one father participated in the study, with ages varying from 23 to 40 years (average 32.4 years). Three caregivers had completed primary school, four completed secondary school and four did not report their educational level.

The age of children varied from two years and four months to 11 years (average 5.2 years old). Of these, four had a diagnosis of acute lymphoblastic leukemia and the remainder varied diagnoses of cancer and myelodysplastic diseases.

In relation to general living conditions, all lived in masonry houses and the average number of rooms was 3.6. The number of residents varied from three to seven and the average was 3.9 residents per house, with ages varying from 2 to 64 years.

Results of semi-structured questions

Semi-structured questions supported the construction of representational figures presented in this section and aim to provide the reader with a written and diagrammatic message of content originated in the interviews.

Verbalization about the process of care delivery to a child with neutropenia at home revealed many expressions of feelings that originated in the changes in the house's organization and dynamics (Figure 1).

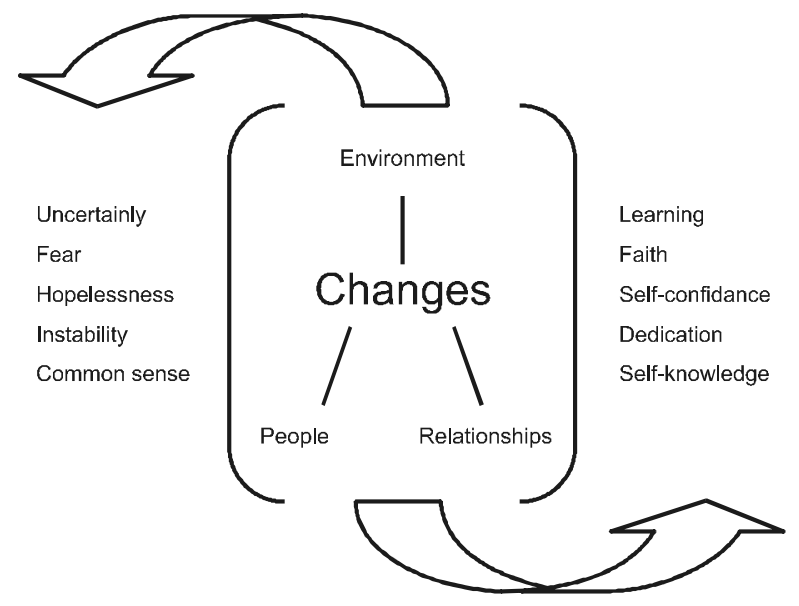

Figure 1 - Representations of caregivers about the meaning of the process of home care for a child with neutropenia. São Paulo, SP, Brazil 2007 


\section{Some reports}

(...) everything changes at home, we start to dedicate ourselves more to her, then you forget a little about yourself. You even forget about your relationship at home (E4).

Caution is doubled because you get worried, there's always a risk, you know?(...) You have to feed the child well, take care of the temperature, take good care of him. The rest is love and affection. And trust in God (E6).

Answers to the question "what procedures generated the greatest doubts?" when dealing with the child at home are grouped in Figure 2.

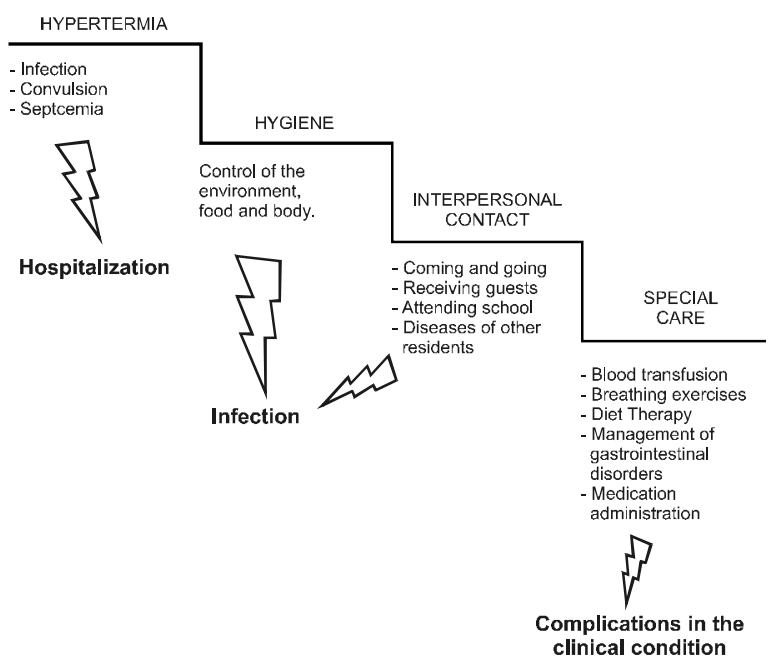

Figure 2 - Care procedures at home that generated the greatest doubts in the perspective of caregivers. São Paulo, SP, Brazil 2007

In response to the question related to the procedures that generated the greatest doubts, questions related to the management of hyperthermia, food and environmental hygiene and prophylaxis of infections prevailed.

Her temperature, I was afraid she'd convulse (E3).

When I saw he had a temperature, everybody started to cry at home; so I left in a hurry to the hospital (...). Everybody takes care of him. If I go to the church, because I'm Christian, my youngest daughter gets the thermometer and stays with it, very concerned. She says: mom, he had no fever (E7).

Other reports evidenced difficulties in the management of social and interpersonal activities, such as transportation and staying in public places, in addition to fear of performing specific care as showed by the following reports:

The other day a little friend of hers, who was on the bus, had chickenpox (...). So I said: don't sit close to the girl, for God's sake (...) (E3).

In the beginning, I'd think at the time of giving medication whether it was going to work, if I wouldn't mess it up (E9).

When she went back home (after the last hospitalization) she had to do inhalation every three, four hours (...) I was scared, it was difficult to do the exercises on the first and second days, but then I learned it too (E2).

When asked about which procedures they needed orientations, interviewees mentioned the following: hygiene followed by questions of affective/ emotional support so as to overcome problems, risks of fall and injuries, medication administration, as well as other procedures related to tube feeding, special diets and intravenous catheters.

In relation to diet preparation and restrictions, the new needs make caregivers adapt, seeking to meet the multiprofessional team's requests and satisfy the child's desires at the same time.

Food is complicated. Because, like... there're things we can eat, but there're others we can't. He eats the basic. We can't give him eggs with soft yolk. So I'd rather not give it. I cross out this kind of food you know - ah, you can, but you have to prepare it like this and that. So, I cross it out and don't give it to him (E10).

Caregivers have better mastery and express more security about care related to house cleansing and food preparation, though these still remain a source of doubts.

Her fruits are left separated, then when I get home, I wash them with tap water and put them in sodium hypochlorite. I sterilize her bottles with hot water. Alcohol, there's alcohol everywhere at home, when in doubt, I put it even on clothes (E2).

Third, interpersonal contacts generate fear and uncertainty related to different activities, such as attending school, going to the movies and shopping mall. The need to use collective transportation was also mentioned as a factor generating insecurity, because it is not under the parents' control and presents a risk of acquiring transmissible diseases.

To start off, you leave here worried, you know? You have to get the bus, it's crowded (E3).

Finally, procedures that are peculiar to the treatment or to its complications and the management of its side effects were also mentioned.

Now that he's being submitted to MTX, he (child) cannot have vitamin $C$, nothing that has vitamin $C$. So, we have to read stuff (food labels) (E10). 
Data related to the question "which procedures you feel needed orientation? could be grouped under care focus (Figure 3 ).

Care focus

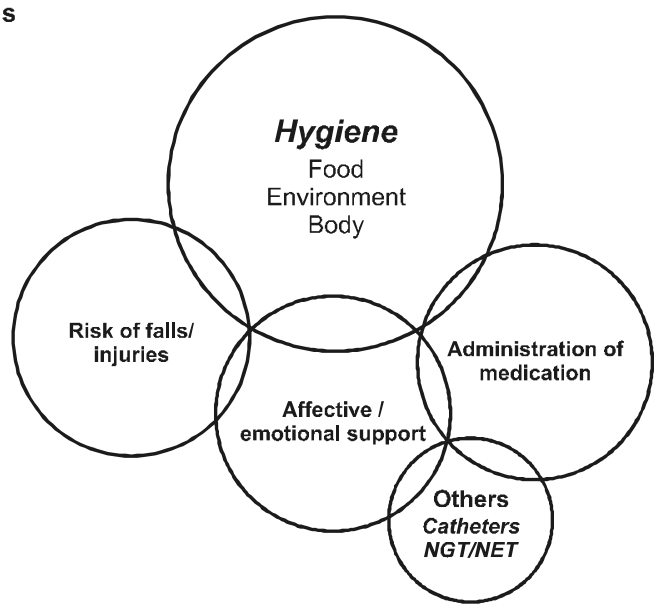

Figure 3 - Procedures on which caregivers of children with neutropenia needed orientation. São Paulo, SP, Brazil, 2007

We present the following reports related to care with food, environmental and body hygiene.

In terms of hygiene, food, we have to keep an eye on everything that happens. They get very vulnerable, helpless and then we have to protect them the best we can (E7).

I guess that you have to care more for his hygiene because the lesser contact he has with bacteria the better. What I take most care with is hygiene of vegetables, I soak everything in a product, peel off the tomato skin (E1).

Procedures related to hygiene were emphasized by seven of the participants as care that needed to be oriented but were also the ones easier to perform because they are already part of their daily tasks. The domestic environment seems to be the only place where caregivers believe to have real control to diminish the risk of infection. Therefore, caregivers believe this is one of the main types of orientation they need.

As mentioned before, the child with cancer might demand care with different levels of complexity. In this perspective, some participants seemed apprehensive to have to perform all procedures in their daily routine and perform them well.

So (in addition to hygiene) you have to prepare food with less salt, almost no salt so as not to raise blood pressure, take the medication, be careful not to fall, not to have hematomas, see the blood, platelets... So, we have to take care of everything (E9).

Pay attention, be very careful and comply with the medication schedule (E8).
Other contents caregivers appointed as needing orientation are related to physical and affective preparedness to cope with and adapt to emotional issues involved in the process of caring for a child with cancer, with increased risks at home due to the neutropenia.

When the child is weak, vulnerable, love is essential (...) be patient, very patient and a lot of willpower (E2).

The most important thing is the father and mother to be together, that'sn it. There're children who have only the mother or the father, but both have to be by his side (E5).

\section{ANALYSIS AND DISCUSSION}

Analyzing the profile of the respondents, we could verify that parents are young and have primary and secondary school, which is a fact to take into account when planning the implementation of educative actions.

With the exception of one interviewed mother, all the others reported they did not have paid jobs as from the moment their children became ill and exclusively dedicated themselves to the family. In terms of living conditions, all of them reported living in masonry houses, though some reports evidenced the risks of exposing children to unsafe material in the external part of the house (debris, recyclable materials).

As shown in Figure 1, the perception of caregivers about the process of caring for children with cancer in the situation of neutropenia is marked by changes that occur in different spheres: environment, people and relationships. In the perspective of theories that explain human reactions in situations that require the use of coping and adapting resources, generally accompanied by stress, these are in a process of transition, which is initiated at the moment the person perceives the crisis. This can be a response to an event seen as a threat, like in the case of neutropenia induced by chemotherapy ${ }^{(9)}$

Transition is a dynamic and regular process, marked by relational and personal changes in the attempt to find new support resources ${ }^{(9-11)}$. For the family, transition is difficult and exhausting. There are moments of anguish, concern and stress, which require the family to reformulate its routine so as to take care of the child and adapt to a new routine that permits maintaining the family unit ${ }^{(10-11)}$. 
In practice, it means continuous adjustment to situations perceived as threatening and difficult, which, to some extent, drive and qualify new ways of thinking and acting, marked by common sense, which under these circumstances are viewed as insufficient by the caregivers ${ }^{(5)}$.

However, we perceived in other reports that the construction of references to care for a child with neutropenia is also shared in relationships established with caregivers of other children. In this aspect, interpretations of common sense can generate doubts or even behavior that compromise the real needs of care to be delivered to the child. This fact was observed in the way one mother expressed the administration of nutritional support, as shown in the following transcript.

The tube, I remember they (other mothers) would say: ah, but I don't give it at the same time, one after the other, as they (nurse) tell you to (E8).

I've always complied with it...I thought that $N$ (daughter) would get clogged, but I thought: it is necessary (E10).

Care practices are strongly influenced by cultural and socioenvironmental determinants and it means that professionals should keep a watchful and intentional eye on the representations of clients and caregivers regarding the content interwoven in care $^{(12)}$. Knowing the meanings attributed by the receptor's message is an essential task when the professional wants caregivers to adopt new behavior, since the construction of symbolic meanings, expressed by their behaviors, comprehends two dimensions: cognitive and affective ${ }^{(6)}$.

With regard to the procedures that generated the greatest doubts, answers were grouped in care procedures related to hyperthermia, hygiene, interpersonal contact and special care.

Care related to hyperthermia was indicated as the main source of concern because caregivers

\section{REFERENCES}

1. Alcoser PW, Rodgers C. Treatment strategies in childhood cancer. J Pediatr Nurs 2003; 18(2):103-12.

2. Bonassa EMA. Efeitos Colaterais dos Antineoplásicos. In: Bonassa EMA, Enfermagem Terapêutica Oncológica. São Paulo (SP): Atheneu; 2005.

3. Washington Manual ${ }^{\mathrm{TM}}$ Hematologia e Oncologia. Rio de Janeiro (RJ): Guanabara Koogan; 2005.

4. Eggenberger SK, Krumwiede N, Meiers SJ, Bliesmer, Earle

P. Family caring strategies in neutropenia. Clin J Oncol Nurs. are informed that hyperthermia is an important clinical sign that suggests severe infectious condition, which poses a risk to the child's life ${ }^{(13)}$.

Three areas are affected by the need to deliver care with more hygiene: preparation of food, environment cleansing and body hygiene.

This new demand involving daily habits generates anxiety, fear and apprehension because these are mostly situations experienced for the first time at home, as evidenced in a study that aimed to identify the general care demands of children and adolescents at home after outpatient chemotherapy, though it did not exclusively focus on neutropenia ${ }^{(14)}$.

Caregivers report that they mirror their behavior and learn how to deal with the child by observing the procedures and orientation provided by nurses, which offers the possibility of establishing teaching-learning situations, conveniently linked to care delivery actions.

\section{CONCLUSIONS}

This study enabled us to understand how caregivers caring for children with neutropenia at home see and react to new and insecure situations that permeate care for children in this condition.

The results indicate the need to prepare caregivers to cope with difficulties inherent to care delivered in a situation that involves so many changes in the environment, in people's lives and relationships, including emotional preparedness for situations in which the children's clinical condition is aggravated.

The current challenge is to transform this study's findings into support, so as to develop a protocol with nursing orientations to caregivers of children with neutropenia at home.

2004; 8(6):617-20.

5. Sá CP. Representações Sociais: o conceito e o estado atual da teoria. In: Spink MJ. O conhecimento no cotidiano. São Paulo (SP): Brasiliense; 1993.

6. Wagner W. Descrição, explicação e método na pesquisa das representações sociais. In: Guareschi P, Jovchelovitch S. Textos em representações sociais. Petrópolis (RJ): Vozes; 2000.

7. Lüdke $M$, André MEDA. Pesquisa em educação: abordagens qualitativas. São Paulo (SP): EPU; 1986.

8. Bardin L. Análise de conteúdo. Lisboa: Edições 70; 1977.

9. Zagonel IPSO. Cuidado de enfermagem na perspectiva 
dos eventos transicionais humanos. Acta Paul Enferm. 1998; $11(2): 56-63$.

10. Nascimento LC, Rocha SMM, Hayes VH, Lima RAG. Crianças com câncer e suas famílias. Rev Esc Enferm USP. 2005; 39(4):469-74.

11. Silveira AO, Ângelo M. A experiência de interação da família que vivencia a doença e hospitalização da criança. Rev Latino-am Enfermagem [periódico na Internet]. 2006 nov [citado 17 mar 2007]; 14(6): 893-900. Disponível em: h t t p : / / w w w . scielo.br/scielo.ph p ? script =sci_arttext\&pid=S0104-11692006000600010\&Ing=. doi: 10.1590/S0104-11692006000600010.
12. Waldow VR. Examinando o conhecimento na enfermagem. In: Meyer DE, Waldow VR, Lopes MJM. Marcas da diversidades: saberes e fazeres da enfermagem contemporânea. Porto Alegre (RS): Artmed; 1998.

13. Huasos MESP. Neutopenia febril en el niño com cáncer: conceptos actuales sobre critérios de riesgo y manejo selectivo. Rev Méd Chilena. 2001; 129(12):1449-54.

14. Costa JC, Lima RAG. Crianças/adolescentes em quimioterapia ambulatorial: implicações para a enfermagem. Rev Latino-am. Enfermagem [periódico na Internet]. 2002 Mai-Jun [citado em 4 jun 2009]; 10(3):321-33. Disponível em: http://www.scielo.br/pdf/rlae/v10n3/13342.pdf. 